\title{
TITLE:
}

\section{Test methods for the determination of biodiesel stability}

$\operatorname{AUTHOR}(S)$ :

Xin, Jiayu; Saka, Shiro

\section{CITATION:}

Xin, Jiayu ...[et al]. Test methods for the determination of biodiesel stability. Biofuels 2010, 1(2): 275-289

ISSUE DATE:

2010-03

URL:

http://hdl.handle.net/2433/158040

\section{RIGHT:}

(c) 2010 Future Science Ltd.; この論文は出版社版でありません。引用の 際には出版社版をご確認ご利用ください。; This is not the published version. Please cite only the published version. 
Title: Test methods for determination of biodiesel stability

\title{
Article type: review paper
}

Summary: Biodiesel, which is defined as mono alkyl esters derived from renewable resources such as vegetable oils and animal fats through transesterification, is an alternative fuel for diesel engines. One of the major drawbacks associated with practical applications is its relatively poor stability compared to petroleum-based diesel. Stabilization of biodiesel is a complex issue including oxidation stability, thermal stability and storage stability. During deterioration of biodiesel, changes of many chemical and physical properties take place and can be monitored by analytical methods. In order to find the relationship between fuel properties and stability during use, several studies have been carried out in this decade, which impelled the establishment of standard analytical methods and special specifications. However, there is still no effective method to determine the storage stability and thermal stability of biodiesel that can cover all oxidation characteristics. In this review, we introduce the methods for stability determination and present comparisons between them. The highest aim of this article is to present the development and implementation of stability test method in research and application fields.

Keywords: biodiesel, oxidation stability, thermal stability, storage stability, specification, standard, accelerated oxidation, autoxidation, Rancimat test

\author{
Authors: Jiayu Xin and Shiro Saka* \\ Graduate School of Energy Science, Kyoto University, Kyoto, Japan \\ Yoshida-honmachi, Sakyo-ku, Kyoto 606-8501, Japan \\ *Corresponding author, Tel: +81-75-753-4738; Fax: +81-75-753-4738. E-mail address: \\ saka@energy.kyoto-u.ac.jp (S. Saka).
}




\section{Introduction}

Biomass is an abundant energy resource that is believed not to release net $\mathrm{CO}_{2}$ when used as a fuel. The global fuel crises in the 1970s triggered awareness among many countries of their vulnerabilities of oil shortage [1]. Considerable attentions were focused on the development of alternative fuel sources, such as bio-based alcohols, biogases and biodiesel. An additional factor that makes biofuel attractive as a fuel extender or substitute is that it is a renewable environmental friendly resource. The shortage of fossil fuel sources and the increasing dependency of the world on crude oil have led to a major interest in expanding the use of bioenergy.

In various biofuels, as an alternative fuel for diesel engines, biodiesel has become more important due to its renewability, biodegradability, compatibility with existing engine technology and low exhaust emissions [2-5]. Actually, the first diesel engine driving test was conducted with vegetable oil (peanut oil) in 1900 at the World's Exhibition in Paris. But due to the fast development and availability in large quantities at low cost of petroleum-based fuel, vegetable oils and animal fats did not become a candidate for diesel engine fuel except for some attempts to use vegetable oils and animal fats as a substitute of petroleum-based diesel during Second World War for the shortage of warfare materials. However, several obstacles prevent the direct use of oils/fats in engines. Firstly, the viscosities of vegetable oils and animal fats are several to ten times higher than petroleum-based fuel. This leads to the feeding difficulty and incomplete combustion [6]. Secondly, some vegetable oils and animal fats have poor cold properties such as cloud point, pour point and cold filtering plug point (CFPP), which cause engine operation problems, pipe plugging problems and even engine breakdown during long time use in cold weather. Lastly, the bad oxidation stability of some high unsaturated fatty acid-containing oils/fats leads to the formation of deposits on the injector nozzles or pipelines and phase separation in diesel tanks. As a result, engine performance deteriorates sooner or later.

In order to use renewable vegetable oil and animal fat resources for diesel engine successfully, pyrolysis, microemulsification and transesterification have been developed to solve above-mentioned problems. Pyrolysis employs the thermal decomposition reaction in the presence of metal salts as catalysts to produce a mixture of alkenes, alkadienes, aromatics and carboxylic acids $[7,8]$, which is similar to petroleum-based fuel in many properties. At the same time, pyrolysis biodiesel is found to have high ash and carbon residue and low cold flow properties. Accordingly, the use of this method has not been widely accepted. Microemulsification is the other method to solve the problem of high viscosity of vegetable oils 
by introducing a co-surfactant into the mixture of oils with methanol, ethanol or 1-butanol, which forms an isotropic, clear or translucent thermodynamically stable dispersion $[9,10]$. However, in a laboratory endurance test, it was found increasing injector needle sticking, carbon deposits and incomplete combustion problems taken place [10].

Transesterification, also called alcoholysis, has been becoming an ideal approach to use vegetable oil and animal fats on engine without modifications, so the word "biodiesel" is now only used to denote products obtained by this technology [11]. Biodiesel fuel, which is defined as fatty acid alkyl esters derived from vegetable oils or animal fats through transesterification, is a renewable, clean and carbon-neutral alternative fuel for diesel engines. Thus, for sustainable development of society and energy, biodiesel has been recently given more attentions [12] and commercially used in many countries.

However, biodiesel is usually very unstable, has an irrepressible tendency to form degradation products like gases, gummy materials and sediments, to change its color, to deteriorate its physical and chemical characteristics and compositions, and to degrade its fuel quality after production. As a result, biodiesel must be used before significant degradations take place. The term "stability of biodiesel" refers to the general resistance of biodiesel to change its fuel properties. Mittelbach divided the biodiesel stability to three types: (1) oxidation stability, (2) storage stability, and (3) thermal stability [13]. Oxidation stability includes the influence of oxygen in the air on biodiesel, thermal stability expresses the influence of temperature $[14,15]$ on biodiesel in the absence of oxygen, and storage stability includes the time factor and storage conditions. Storage stability of biodiesel highly relates with oxidation stability, which is the ability of biodiesel resisting to the deteriorating effect of existing oxygen in the air in storage over extended period of time with satisfactory fuel properties. For the same storage conditions, a high oxidation stability biodiesel always ensures good storage stability. "Thermal stability of biodiesel" may be defined as the ability of biodiesel resisting to the relatively high temperature stress for short period of time with satisfactory fuel properties. Biodiesel tends to be very thermally stable but less stable in oxidation when compared to petroleum-based diesel. Degradation of biodiesel shows various behaviors including color change, production of soluble and/or insoluble gums, development of sediments or deposits, formation of cokes, changes in physical properties, chemical properties and compositions, influencing on emission profile and worsening the compatibility with other fuels.

From the previous studies, it is evident that the whole feature of biodiesel degradation is very complicated. There is no single explanation for all of the phenomena in degradation of biodiesel. However, 
all researchers agree that the instability of biodiesel is associated with oxidation/ autoxidation of fatty acid methyl esters, especially unsaturated fatty acid methyl esters. With the proceeding of oxidation reaction, a change in chemical composition of biodiesel, along with the physical properties such as viscosity, color, density, cold filter plugging point (CFPP), pour point and flash point, tends to decrease the quality of biodiesel being off the fuel specification.

Biodiesel stability is expected to become more noticeable in the future due to the growing production of bioenergy and shortage of petroleum storages. A reliable laboratory technique for the characterization and prediction of the stability of biodiesel had been a crux after industrialization of biodiesel. Several researchers have conducted the long-term storage tests to establish the reliability and accuracy of an accelerated test or to define whether the biodiesel is stable or not. Many organizations and researchers have carried out a considerable amount of work on biodiesel stability on fuel properties. However, at present, there is no accurate method commonly accepted for the prediction of biodiesel instability from various sources and under various conditions of storage.

\section{Foundation of oxidation stability test of biodiesel}

\subsection{Autoxidation of biodiesel}

Most hydrocarbon-based materials deteriorate due to the chemical reaction with oxygen in the air. Scientists has recognized that autoxidation is a common factor in the loss of physical properties of rubbers and plastics [16,17], rancidification of fats and oils[18,19], deterioration of lubricating oils and jet fuels $[20,21]$ and even some diseases in vivo $[22,23]$ for a long time. Autoxidation of rubber was first recognized by Ostwald to be associated with the absorption of oxygen in the early 1900's [24]. Once it was fully understood and accepted that autoxidation of hydrocarbon involves allylic groups and proceeds through free radical chain reaction in the middle 1920's [25]. In this theory, the oxidation of hydrocarbon-based materials was recognized that the reaction was catalyzed by its oxidation products. 


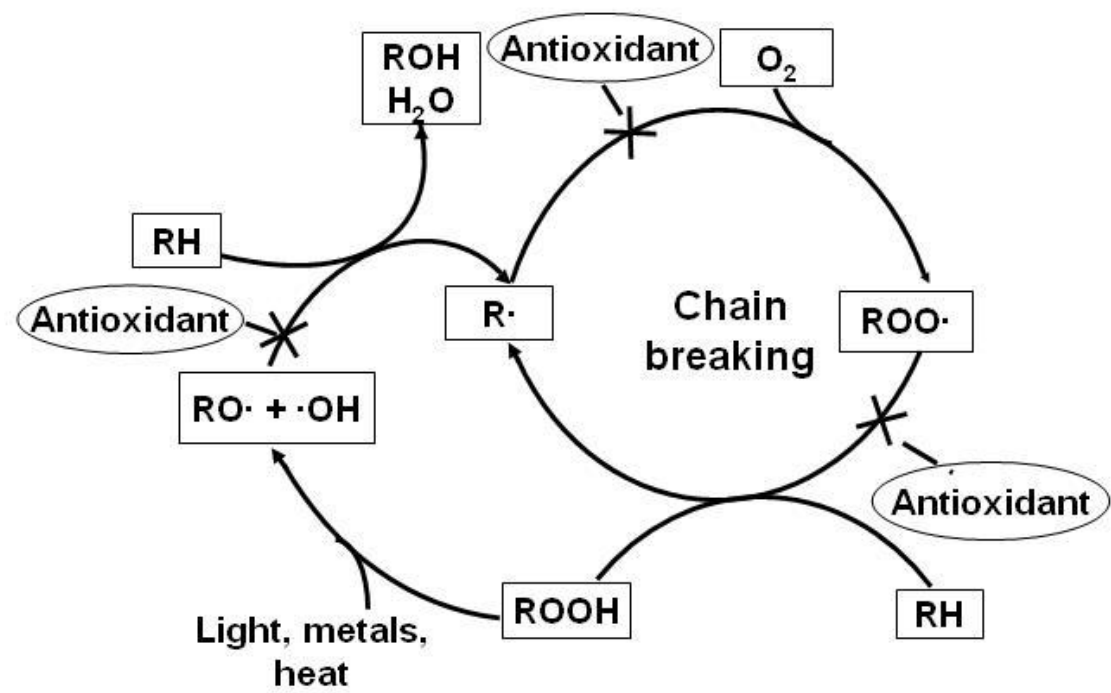

RH: Fatty acid methyl ester

ROOH: Hydroperoxide

ROO $\bullet:$ Hydroperoxyl radical

$\mathrm{R} \cdot$ : Alkyl radical

RO $\bullet:$ Alkoxy radical

- OH: Hydroxyl radical

Fig. 1 Reaction mechanism of oxidation and antioxidation of fatty acid methyl ester [26]

(Reprinted with permission from ref 56. Copyright 2006 Industrial Publishing \& Consulting, Inc.)

Figure 1 shows the reaction mechanism of oxidation and antioxidation of fatty acid methyl ester RH [26]. The autoxidation of poly-unsaturated methyl ester in biodiesel is considered to start by abstraction of a hydrogen radical from the internal allylic position between two $\mathrm{C}=\mathrm{C}$ double bonds and to form free radical $\mathrm{R}$ in the presence of oxygen, light, metal ions, heat and so on. Hydrogen radical abstraction is prone for bis-allylic internal position during the initiation step of oxidation because of its low dissociation energy of the $\mathrm{C}-\mathrm{H}$ bond. The unpaired electron of the newly formed radical delocalizes in the double bond system, and thereafter, the oxygen dissolving biodiesel is connected to one side of double bond to form highly reactive radical $\mathrm{ROO} \cdot$. These radicals regenerated during the initial stage of autoxidaiton have very high reactivity, which continuously react with fatty acid methyl ester RH to produce new highly reactive free radicals. Moreover, the free radicals are also replenished by homolysis of hydroperoxide $\mathrm{ROOH}$. The homolytic cleavage of hydroperoxides ( $\mathrm{ROOH})$ between these two oxygen molecules is regarded as the most likely hydroperoxide decomposition pathway [27]. This reaction yields an alkoxy radical (RO•) and a 
hydroxy radical $(\bullet \mathrm{OH})$. The alkoxy radical $(\mathrm{RO} \bullet)$ can enter into a number of different reaction pathways as shown in Fig. 2. Alkoxy radicals can attack another unsaturated fatty acid, a pentadiene group within the same fatty acid or the covalent bonds adjacent to the alkoxy radical. Cleavage of the hydrocarbon chain by alkoxy radicals on the methyl end of the fatty acid will produce smaller molecular compounds. Beside cleavage of the fatty acid chain, the produced radicals will interact with a variety of compounds to produce secondary lipid oxidation products such as aldehydes, ketones, alcohols, furans, hydrocarbons and acids as listed in Fig. 2.

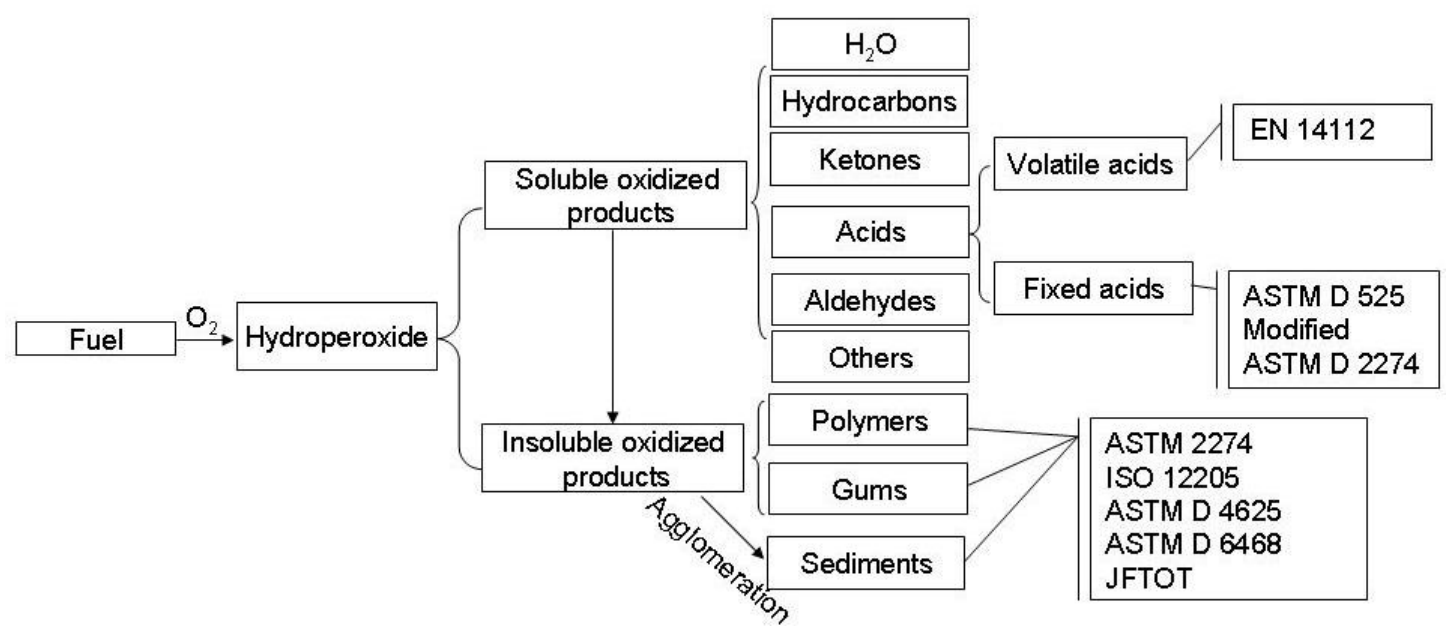

Fig. 2 The overall process of fuel oxidation

Fortunately, biodiesel prepared from vegetable oils always contains different concentrations of naturally gained antioxidants [28,29]. As shown in Fig. 1, if the antioxidant is added into the system, the reaction chain would be cleaved by the reaction between free radicals ( $\mathrm{ROO} ; \mathrm{R}$ and $\mathrm{RO} \bullet$ ) and antioxidant until the antioxidant is consumed to a critical concentration.

\subsection{Formation of low molecular weight oxidation products}

The primary oxidation products, hydroperoxides, are relatively stable at room temperature and in the absence of metals. However, with the accumulation of hydroperoxides or at high temperature, they are readily decomposed to alkoxy radicals and then form aldehydes, ketones, acids, esters, alcohols, and short-chain hydrocarbons [30] as shown in Fig. 3 [31] as well as high molecular compounds such as polymers, gums and sediments as shown in Fig. 2. The most likely pathway of hydroperoxide decomposition is a homolytic cleavage between oxygen and the oxygen bond, in which alkoxy and hydroxy radicals are produced [31] and many secondary oxidation products of autoxidation of fatty acid methyl 
ester are produced from homolytic cleavage mechanism [32]. Formation of hydroperoxide [33,34] will damage elastomeric gasket materials in the engine combustion mechanical system. It has been proven for a long time that only few compounds are not by the formation of hydroperoxides [35,36]. Although saturated methyl esters are relatively inert, they also form hydroperoxides, which are converted mainly to ketones and alcohols with the ketones predominating.

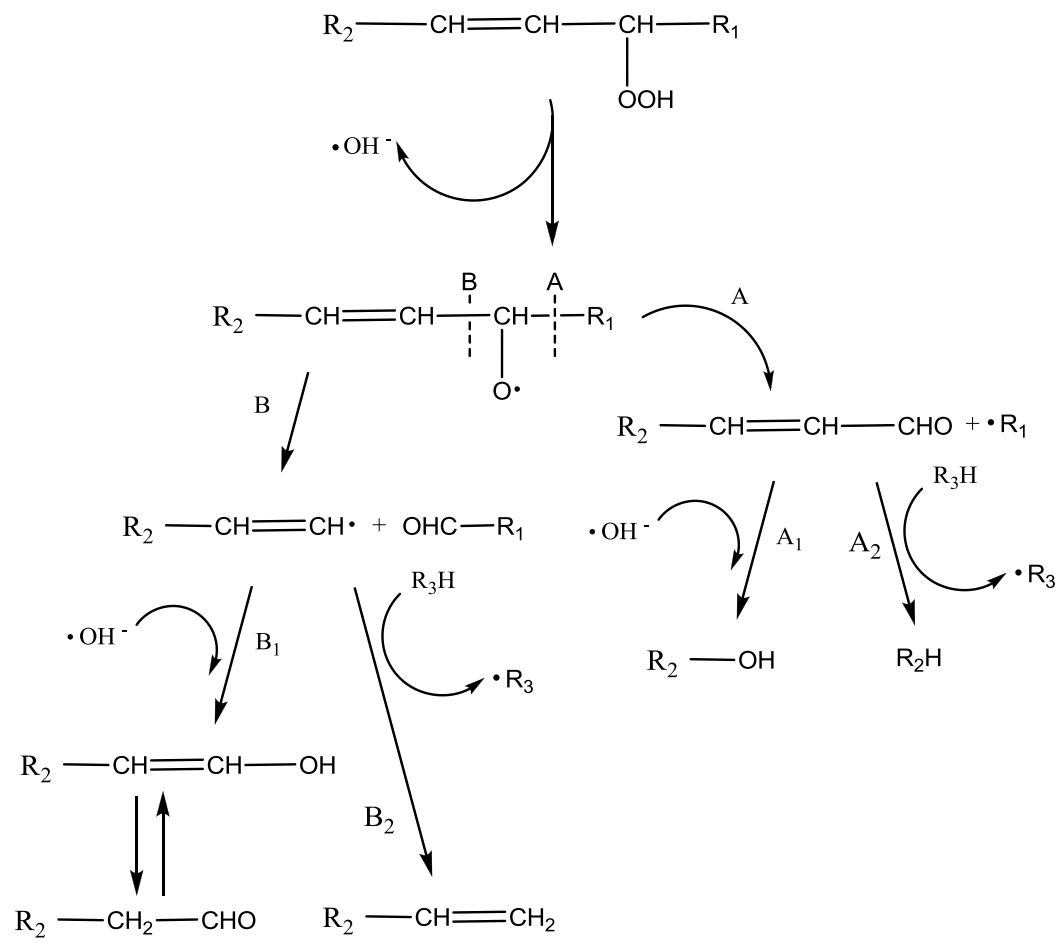

Fig. 3 Mechanism of hydroperoxide decomposition to form secondary oxidation products [31]

(Reprinted with permission from ref 31. Copyright 2006 Wiley-Blackwell)

One of the secondary products, carbonic acid, can corrode metals used in vehicle and distribution fuel handling systems. The impact of acids on metal fuel tank is especially severe. Further produced carbonic salts cause deposits inside the fuel pump and injectors. Polymers, deposits and other insoluble materials formed during oxidation can cause fuel filter blocking. Some of the produced salts, are soluble in the fuel, pass through the fuel filter, but stick to the surfaces of the fuel pump and fuel injectors. Short chain carboxylic acids such as formic acid and acetic acid are miscible with water and dissociate to form reasonably strong acids (pKa 3.77 and 4.76, respectively), as shown in Fig. 3, which lead to the increase in acid value of biodiesel. Longer-chain fatty acids do not show a great change in pKa. However, as the chain length increases, the solubility of the fatty acids in water decreases very rapidly, so that the longer-chain fatty acids have very little effect on the $\mathrm{pH}$ value of a water solution. Standard method ASTM D 525 was developed by measuring the remained carboxylic acid in the oxidation process. The significance of their 
pKa values therefore has relevance only to the types of reactions in which they can take part in. If biodiesel is heated up, part of short chain carboxylic acids would be evaporated from biodiesel. Standard method EN14112 was developed by measuring the evaporated carboxylic acids produced during the oxidation process.

After oxidation reaction, some oxidized products may have different dielectric constants with fatty acid methyl ester, and fatty acid methyl ester is always mixed with petroleum diesel as diesel fuel. If some special products such as water and polymers reach a concentration high enough, immiscible between oxidized products and fuel mixture can be found. Furthermore, it is reported that fungi can grow and form coherent matter at the oil-water interface, leading the increase of emulsified water in the fuel [37]. Therefore, compatibility of each fuel component should be of significant importance after long time storage due to the production of oxidation product.

\subsection{Formation of high molecular weight oxidation products}

For hydroperoxide decomposition, oxidation linking of fatty acid chains to form dimer, trimer and oligomer structures with conjugated diene systems were regarded as the main route to form high molecular oxidation compounds of esters in the presence of a free radical initiator and absence of oxygen [38]. Polymerization of oxidized methyl linolenate in the absence of air produced a complex mixture of oxygen-containing compounds, including $70 \%$ dimers; the rest consisted of trimers, oligomers and carbonyl and hydroxy compounds [39]. While in another study, it was found that almost all of the secondary products formed from hydroperoxide decomposition are dimers at the beginning, while polar monomeric and low molecular products are negligible [40]. With the decomposition reaction proceeds, more polar monomeric and low molecular compounds could be formed, but dimers and polymers are still the major products. The dimers isolated from the autoxidation of methyl linoleate hydroperoxides at low temperature are composed of unsaturated fatty ester units crosslinked through either peroxide or ether linkages and contained hydroperoxy, hydroxy and oxo groups [40]. Peroxy-linked dimers and small amounts of ether-linked dimers were also identified from decomposed linoleate hydroperoxides [28]. Therefore, it can be concluded that the C-O-O-C and C-O-C linkages should be characteristic of polymerization carried out under the mild conditions. These structures are different from those dimers formed in the thermally decomposed methyl linoleate hydroperoxides, which are linked through C-C bonds [39]. 
<smiles>[R]C(C)CC</smiles>
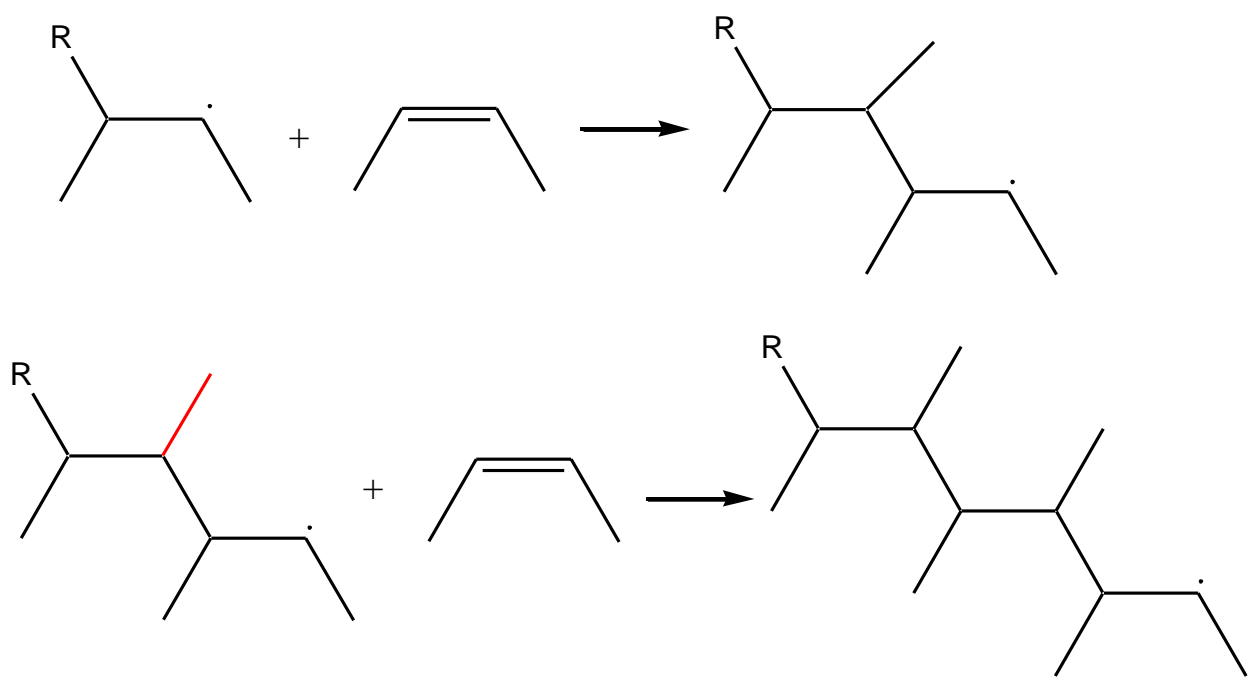

Fig. 4 Reaction mechanism of vinyl polymerization [41]

(Reprinted with permission from ref 41. Copyright 1979 Wiley-Blackwell)

Another polymerization mechanism, vinyl polymerization [41], has been proposed as being part of the degradation process of fatty oils and esters. As shown in Fig. 4, a free radical adds directly to a $\mathrm{C}=\mathrm{C}$ bond to create a $\mathrm{C}-\mathrm{C}$ bond and another free radical. This dimer can abstract a hydrogen from another molecule or continue the process by adding to a $\mathrm{C}=\mathrm{C}$ bond with another fatty oil or ester. It should be noted that polymerization is highly related with unsaturated ester content, especially poly-unsaturated ester like linolenic acid. Therefore, both linolenic acid content and iodine value are required minimum contents in biodiesel specification.

Thermal polymerization of fatty oils and esters does not become important at temperatures lower than $250^{\circ} \mathrm{C}$. This is because the methylene-interrupted poly-unsaturated structure cannot participate in such reactions until it isomerizes into a conjugated configuration, and such isomerization will not occur until such a temperature above $250^{\circ} \mathrm{C}$ is reached. Rates of thermal polymerization showed a stronger dependence on the degree of unsaturation than oxidative polymerization. For example, relative rates of oxidative polymerization of oleic and linoleic safflower were $1: 3$ at $260^{\circ} \mathrm{C}$. Relative rates of thermal polymerization of the same composition oils increased 10 times at $320^{\circ} \mathrm{C}$ [42]. During the thermal polymerization of biodiesel, oligomers are also produced at high temperature, although the exact mechanism is still not 
established and verification of such compounds and their impact on fuel quality have not been determined. The temperature of biodiesel before injecting to engine is always lower than the temperature of thermal polymerization except for some specific circumstances. Besides, thermal polymerization does not impact storage stability. Therefore, thermal stability of biodiesel is less important than oxidation stability.

\section{Test methods for stability of biodiesel}

Reliable methods for the prediction and determination of biodiesel stability have been desired to measure the various factors associated with biodiesel oxidation. Many researchers carried out plenty of works on its stability characterization and test studies, and the long term storage test was concluded to establish the reliability and accuracy of a standard test [14,43-47]. For the acceptance for all biodiesel producers and consumers, the test method must give a reliable predictive answer in a reasonably short test time with simply accelerating techniques. However, at present, there is no adequate test method universally accepted to predict the stability of biodiesel blended from various sources and/or under different storage conditions.

Based on the reaction rate of fuel oxidation under test condition, stability of biodiesel test can be divided into two categories: the long term storage stability test and accelerated stability test. The former test monitors fuel properties change along the simulated storage conditions, while the latter test employs an elevated temperature and/or oxygen/air aeration to accelerate the reaction rate. It is not reasonable to use the long term storage stability test as a standard test because the reliable result must be obtained in a reasonably short time, unless some intended research purposes exist.

\subsection{Accelerated stability test}

\subsubsection{Rancimat method}

\subsubsection{Determination mechanism}




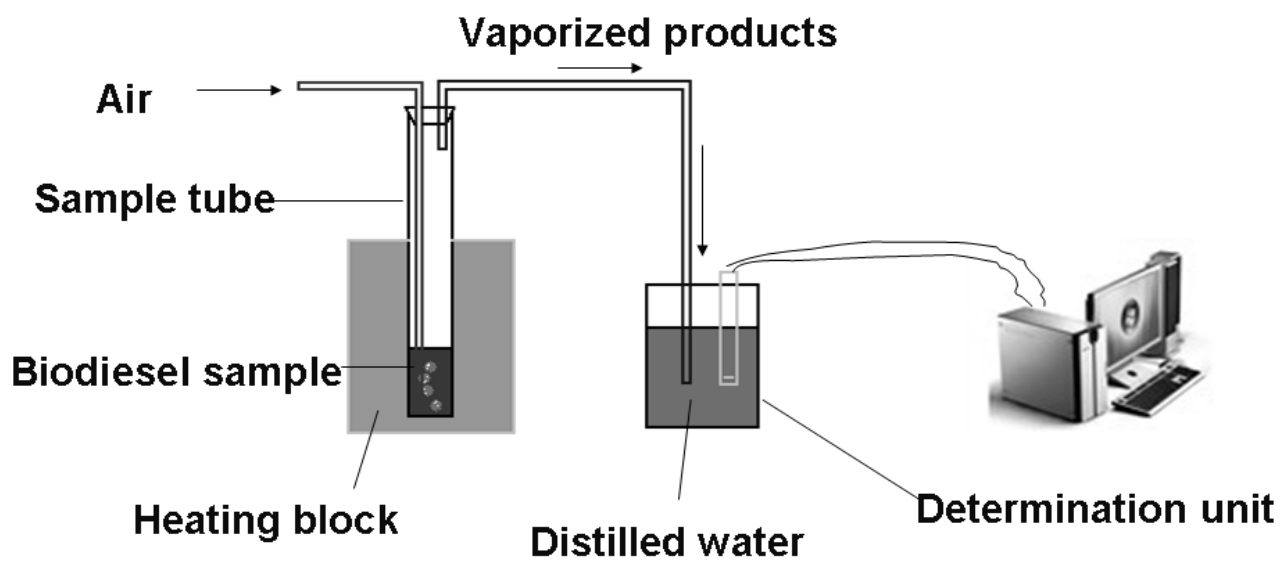

Fig. 5 Schematic measuring arrangement of the Rancimat test

For EN 14214 method, commercially available instrument named Rancimat 743 has been sold for determining the oxidation stability of oils and fats produced by Metrohm, Switzerland. The Rancimat method is based on determination of the time for the sudden change of oxidation rate by measuring the increase in the conductivity of distilled water caused by the carried volatile acids [48] in air bubbled from the heated sample. As shown in Fig. 5, a sample is heated to $110^{\circ} \mathrm{C}$ by a heating block, and then the purified air passes though the heated sample to a determination unit containing distilled water. In the determination unit, the conductivity change of distilled water caused by volatile short-chain carboxylic acids from decomposed products of hydroperoxide is recorded by a computer continuously. The end point is indicated by the intersection point of two tangent lines along conductivity curves as shown in Fig. 6. The time from the beginning to the intersection point is named induction period, which provides a good characteristic value for the oxidation stability.

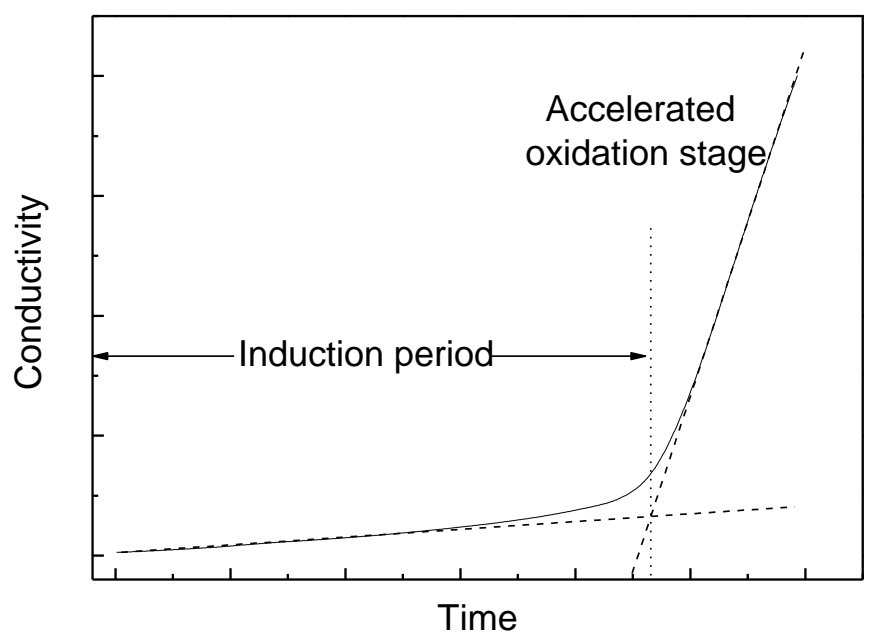

Fig. 6 A typical conductivity curve of biodiesel oxidation as determined by Rancimat test 
From Fig. 6, it is clear that the oxidation can be separated into two stages, slow oxidation stage and accelerated oxidation stage. In accelerated oxidation stage, oxidation rate is greatly higher than the initial stage. As a result, fuel properties of biodiesel degrade quickly especially for some items related with oxidation such as kinematic viscosity, acid value, flash point, carbon residue, and ester content, iodine value, copper corrosion, etc [14,49].

\subsubsection{Development and acceptance}

The Rancimat method was developed as an automated version of the extremely time-consuming and complex active oxygen method (AOM) for determining the induction period of fats and oils. Both authoritative biodiesel standards EN 14214 [50] and ASTM 6751-08 [51] require that Rancimat method should be used to determine the oxidation stability of biodiesel. The Rancimat apparatus is based on an accelerated method to assess oxidative stability of fats and oils and their derived products developed by Hadorn and Zurcher [52] more than 30 years ago. This method has gained wide acceptance owing to its ease in use and high reproducibility. ISO $6886[53,54]$ uses this method as the standard method, and EN 14112 was established based on the modification of ISO 6886 for determination of oxidation stability of neat biodiesel (B100). Until now, EN 14112 has been accepted by European countries, US [51,55,56], China [57], Thailand, India, New Zealand, The Philippines, Korea and Brazil as the reference standard and will be possibly accepted by Australia [201].

The most important work for the implementation and standardization of Rancimat test as the standard method for oxidation stability of biodiesel was finished in 2003 by a group of nine European industrial and research laboratories, called "BIOSTAB" (biodiesel stability) [58]. The research group conducted an extensive study on different test methods for measuring the oxidation stability of fatty acid methyl esters made from rapeseed, sunflower, tallow and used frying oil. BIOSTAB reported that the Rancimat test provides a very good index of oxidation stability for fatty esters displaying a range of stability levels. They also reported that the evolution of fuel quality parameters such as acid value, peroxide value, polymer content, and others were correlated with the change of the induction period during oxidation along with Rancimat test at $110^{\circ} \mathrm{C}$. Later, the Southwest Research Institute tested the EN 14112 and ASTM D 2274 methods with 27 samples. It was, then, concluded that considerable work remains to be done in order to determine an appropriate test and limit for biodiesel oxidation stability [59].

It is easy for the commercialization of biodiesel blended with petroleum-based diesel other than neat biodiesel (B100). The most common biodiesel blends are B2, B5, B10, B20 and B50. EN 14112 was 
applicable to B100. For adapting to the market, the blended biodiesel with petroleum-based diesel also need to be tested. As a result, in CEN/TC 307, the modifications to EN 14112 are given to allow application of Rancimat test method for oxidation stability for neat biodiesel and diesel/biodiesel blends at various levels. Although the modification covers various biodiesel blends with petroleum-based diesel, CEN/TC 307 decided that it was better to retain EN 14112 for neat biodiesel and publish a separate standard for all automotive fuel and heating oil applications [60].

Petroleum-based diesel is produced from the fractional distillation of crude oil between $170^{\circ} \mathrm{C}$ and $410^{\circ} \mathrm{C}$ at atmospheric pressure, resulting in a mixture of carbon chains that typically contain between 8 and 21 carbon atoms per molecule. If the testing time is too long, some short chain compounds may evaporate from sample tube. Furthermore, blended diesel fuel with significant amount of biodiesel gives very good repeatability by using Rancimat test, but its conductivity with high petroleum-base diesel (B5) increases very slowly with oxidation time due to the reduction in sample amount and gives a poor repeatability. Sometime, the biodiesel sample decreases to a level lower than the inlet of purified air tube, so that bubble can not be formed for well aeration. In order to determine the oxidation of blended diesel with biodiesel, the draft standard EN 15751, an alternative to 16 hour EN 12205 [61] sludge-test specified in EN590 [62] was published [60]. The modified EN 15751 accounts the volatility of petroleum-based diesel and the longer stability of blends by increasing the reaction tube length to $250 \mathrm{~mm}$ and increases the minimum analysis time to 20 hours. The vaporized petroleum portion of the blended sample may be condensed on the surface of plastic seal of the sample container and in the tube between sample container and determination unit and even in the determination unit, where, the temperature is lower than dew point of petroleum portion. Some of these parts may need to be replaced frequently, and all components should be thoroughly cleaned to prevent falsely low readings. Improvements to these parts and potential changes in the test method are currently being evaluated [63].

In US, before the acceptance of EN 14112 as the standard specification of the national biodiesel standard, specification of oxidation stability of biodiesel was not included in the standard, which is a main barrier to increase the acceptance by customers for the quality of fuel. Therefore, the item of oxidation stability testing by Rancimat method was included in the later approved standard [64]. ASTM Committee D02 on Petroleum Products and Lubricants also indented to use ASTM D 2274 as the standard method for oxidation stability of biodiesel, but correlation of this test with actual storage stability is unknown, and may depend upon field conditions and fuel composition [65]. 
One significant difference regarding the use of the Rancimat test in EU countries and US is that most of the B100 produced in EU is derived from rapeseed oil, which has relatively high oxidation stability. Most of the biodiesel produced in US is, however, derived from soybean or yellow grease, which has a low induction period of $1-2 \mathrm{~h}$. The induction period tested by Rancimat test is required to be longer than $3 \mathrm{~h}$ and 6h in ASTM D 6571-08a [51] and ASTM D 7467-09a [63]. A quality survey [66] of the biodiesel blends sold in 24 retail stations in March and April 2007 in US showed only over 55\% of the samples met the ASTM standard 7467-09a for the B20 of an induction period of $6 \mathrm{~h}$ or longer.

Measuring oxidation stability only by the Rancimat method may be inadequate, because this test only evaluates the fuel's acid forming tendency and cannot evaluate its tendency to form polymers and deposits, which are also very important for the successful operation of engine.

\subsubsection{Accelerated oxidation method of distillate fuel oil at 95 or $115^{\circ} \mathrm{C}$}

\subsubsection{Determination mechanism}

Accelerated oxidation method of distillate fuel oil [67] ASTM D 2274 is widely accepted as the standard method for many countries and commonly used in petroleum industry as a quality control test. This method uses elevated temperature and pure oxygen as oxidizer to accelerate the oxidation of fuel. $350 \mathrm{ml}$ fuel is stored at $95^{\circ} \mathrm{C}$ with oxygen bubbling at a rate of $3 \mathrm{~L} / \mathrm{h}$ for $16 \mathrm{~h}$. After artificially aging and cooling, the filterable and adherent insolubles are filtered by a matched pair $47 \mathrm{~mm}$ diameter cellulose ester surfactant-free membrane filters with a nominal pore size of $0.8 \mu \mathrm{m}$. In this method, the formation of polymer and sediment are determined. In B100 biodiesel, the polymer formed during storage condition is soluble due to the similar polarity of polymer and biodiesel, but it would become insoluble when oxidized biodiesel is mixed with petroleum diesel [58].

\subsubsection{Development and acceptance}

ASTM D 2274 method has been used in many countries including non-ASTM countries for over 30 years. Many researchers spent tremendous efforts on the relation between accelerated test and long term storage test, but it was proven that there is no correlation between them under normal conditions. High temperature and pure oxygen venting make the oxidation reaction not to take place under storage condition. Because neat biodiesel can not pass the cellulose ester surfactant-free membrane filter, ASTM D 2274 can not be used directly for determining the oxidation stability of B100 biodiesel. Therefore, US National Renewable Energy Laboratory and Southwest Research Institute carried out extensive studies to modify 
this method for oxidation stability testing of biodiesel. They tried to use glass fiber filters, varying times and temperatures. However, the modification has not been approved by American Society for Testing and Materials organization now [68]. For the same sake that neat biodiesel cannot pass the cellulose ester surfactant-free membrane filter, it is also hard to use ASTM D 2274 to determine the blended fuel with high concentration of biodiesel. For example, some fuel samples can not be filtered if the biodiesel blends are higher than $15 \%(\mathrm{v} / \mathrm{v})$. Even some fuel samples can be narrowly filtered by cellulose ester surfactant-free membrane, the reproductively of determination results becomes too low.

The modified ASTM D 2274 in the specifications for biodiesel was accepted by Engine Manufactures Association of American (EMA) as the standard method for testing the oxidation stability of biodiesel [69], in which the speciation required that the insolubles formed in the test must be lower than $10 \mathrm{mg} / 100 \mathrm{~mL}$. Until now, the modified ASTM D 2274 as the standard method for oxidation stability test and under approving process of ASTM Committee D02 on Petroleum Products and Lubricants named ASTM D 7462 [70].

In Japan, there is no exact oxidation stability specification for biodiesel blend stock for automobile fuel [71], but the blended fuel is required to satisfy the diesel fuel specification after blending with biodiesel, which is more strict than EN and ASTM standards. Unlike the fuel tanks of cars are made by plastic in Europe and US, most fuel tanks in Asia are made by metal. Table 1 shows a summary of metal sheet corrosion test in biodiesel at $120^{\circ} \mathrm{C}$ for $1000 \mathrm{~h} \mathrm{[72].} \mathrm{It} \mathrm{indicates} \mathrm{that} \mathrm{after} \mathrm{the} \mathrm{long} \mathrm{time} \mathrm{storage} \mathrm{of}$ oxidized biodiesel, corrosion of metal is very serious and can not be neglected. Therefore, metal corrosion, especially acidic corrosion after degradation of biodiesel is of significant importance for the cars in Asian countries and a more strict specification is needed.

Table 1 Summary of metal sheet corrosion test in biodiesel at $120^{\circ} \mathrm{C}$ for $1000 \mathrm{~h}$

\begin{tabular}{|c|c|c|c|c|c|}
\hline Metal & $\begin{array}{r}\text { Weight before } \\
\text { test }(\mathrm{g})\end{array}$ & $\begin{array}{l}\text { Weight after test } \\
\qquad(\mathrm{g})\end{array}$ & $\begin{array}{l}\text { Weight } \\
\text { Change }\end{array}$ & $\begin{array}{l}\text { Acid value increase } \\
\qquad(\mathrm{mgKOH} / \mathrm{g})\end{array}$ & $\begin{array}{r}\text { Metal concentration in biodiesel } \\
\text { after test (ppm) }\end{array}$ \\
\hline & & & $(\%)$ & & \\
\hline $\mathrm{Fe}$ & 3.414 & 3.415 & 0.03 & 0.31 & $<1$ \\
\hline $\mathrm{Al}$ & 1.098 & 1.103 & 0.46 & 4.94 & $<1$ \\
\hline $\mathrm{Cu}$ & 3.820 & 3.821 & 0.03 & 0.29 & $<1$ \\
\hline $\mathrm{Zn}$ & 3.086 & 2.985 & -3.27 & 1.22 & 750 \\
\hline
\end{tabular}


In Japan, diesel fuel specification requires the oxidation stability to be determined according to a modified ASTM D 2274 method. In this method, there are two differences from ASTM D 2274: 1) test temperature is set at $115^{\circ} \mathrm{C} ; 2$ ) test item, acid value in blended fuel other than insolubles, should be lower than $0.12 \mathrm{mgKOH} / \mathrm{g}$. Even biodiesel has an induction period longer than $6 \mathrm{~h}$, the $\mathrm{B} 5$ blended fuel can not meet this requirement [202]. The oxidation stability of biodiesel test according to EN 14112 longer than $10 \mathrm{~h}$ is essential to prevent metal corrosion [73].

\subsubsection{Storage stability at $43^{\circ} \mathrm{C}$}

\subsubsection{Determination mechanism}

To test the fuel stability at $43^{\circ} \mathrm{C}$ has a wide spread of acceptance for its good correlation with actual fuel performance in petroleum industry. In this test, $400 \mathrm{ml}$ filtered fuel is aged in a borosilicate glass container at $43^{\circ} \mathrm{C}$ for $0,4,8,12,18$ and 24 weeks. After aging for a selected period, filterable insolubles and adherent insolubles of the sample taken from the container are analyzed gravimetrically. Test results have been shown to predict storage stability more reliably than other accelerated tests for its propinquity to the real storage temperature. In order to evaluate the oxidation stability of biodiesel in a reasonably short time, accelerating the oxidation rate by increasing the temperature is needed. But the rate of oxidation of different fuel with different composition does not change uniformly as temperature is increased. Furthermore, compositions of filterable insoluble and adherent insoluble formed from oxidation for the same fuel vary under different temperatures. Effect of temperature on these variables is minimized at $43^{\circ} \mathrm{C}$ [74].

\subsubsection{Development and acceptance}

It has been long accepted that the oxidation of fuel at $43^{\circ} \mathrm{C}$ in an approximately 4 times acceleration at an ambient temperature of $21^{\circ} \mathrm{C}$. In another word, storage of fuel at $43{ }^{\circ} \mathrm{C}$ for a week is roughly equivalent to that storage at ambient temperature for a month. Although this test method simulates the real storage condition as much as possible, the time consuming and non-automatic determination make it a poor choice for oxidation stability test. McCormick and Westbrook [75] regard that storage stability at $43^{\circ} \mathrm{C}$ is a good method to determine the oxidation stability of petroleum-base fuels but not for B100 because degradation reactions occurred in $\mathrm{B} 100$ are accelerated much more by increasing the temperature to $43^{\circ} \mathrm{C}$ than those occurred in conventional diesel fuels at this temperature. This method has been evaluated by 
several research groups [58,59][203] for the development of the method of biodiesel oxidation stability test, but none of them recommended it as a specification method.

\subsubsection{Rapid small scale oxidation test}

Most recently, a new method named "Rapid small scale oxidation test (RSSOT)" [76] for the determination of oxidation stability of middle distillate fuels such as diesel fuels and heating oils covering up to $100 \%$ biodiesel by an commercially available automatic instrument was issued by ASTM Committee. A $5 \mathrm{ml}$ fuel sample is oxidized in a pressure vessel initially filled at 15 to $25^{\circ} \mathrm{C}$ with pure oxygen pressure at $700 \mathrm{kPa}$ and heated up to a temperature of $140{ }^{\circ} \mathrm{C}$. The pressure is recorded continually until the pressure in the test apparatus is $10 \%$ below the maximum pressure of the actual test run (break point). The time from the starting, the heating procedure of the sample vessel and the break point is defined as induction period. Now, this method is under the jurisdiction process of ASTM Committee D02 on Petroleum Products and Lubricants and will be possibly included in the newly published standard in the future [76]. The specification requirement for this method is not now available either.

\subsubsection{Other methods}

Other methods for the oxidation stability test of biodiesel have been evaluated including JFTOT method, induction period method, high temperature stability and potential residue method, and thermal analyses such as thermogravimetry (TG), differential scanning calorimetry (DSC) and differential thermal analysis (DTA) [77-80]. All of them measure one or several items along with oxidation including primary oxidation products, secondary oxidation products or physical property changes. Evaluations for these methods as standard method for oxidation stability test of biodiesel are not enough because Rancimat test and Accelerated oxidation method at 95 or $115^{\circ} \mathrm{C}$ have already been selected by standard committees.

\subsection{Long-term storage test}

Maybe the first study of long-term storage test for fatty acid methyl ester as automobile fuel was investigated by Du Plessis et al. [81,82]. In this study, Du Plessis et al. studied the influence of air, temperature, light, antioxidant and storage container on acid value, peroxide value, viscosity and induction period of methyl and ethyl fatty acid esters of sunflower seed oil for a 3-month storage. It was found that high temperature, light and air exposure, and rust of storage container are not favorable for the long time 
storage of biodiesel. Later, Bondioli et al. [83] studied the chemical and physical changes of the biodiesel sample prepared from rapeseed oil stored at different temperatures, conditions and in containers. It was found that oxidation rate varied at different temperatures as well as the different oxidation paths taking place in different containers. Similarly, Mittelbach and Gangl [84] studied degradation of biodiesel from rapeseed and used frying oils under different storage conditions. Storage effects of air and light exposure on oxidation were observed in this study. Bondioli et al. [85] investigated biodiesel samples from different producers stored for one year in 200L drums. Fifteen different fuel properties were recorded periodically; dramatic changes in peroxide value and viscosity were found. Similar changes for fuel properties along long-term storage were also observed in other studies [43,86-90]. It can be concluded that storage stability of biodiesel can be influenced by storage condition, temperature, humidity, sunlight, the presence of antioxidants and contaminants $[49,91,92]$. Such long-term storage test methods have fully evaluated fuel property changes along storage under the real utilization circumstance and provided us valuable data on biodiesel storage and storage stability for only research purpose, but it is impossible to adopt such a kind of method for the specification test.

\section{Comparison of some oxidation stability test methods}

A summary of existing oxidation stability test methods for biodiesel is listed in Table 2 . The methods are mainly differing in test condition, sample amount, test temperature and aging time. Fuel properties affecting the stable operation of an engine using biodiesel or blended fuel include viscosity, acid value, sediment and polymer content, none of the method can cover all values. All methods use elevated temperature and/or air/oxygen agitation to accelerate the oxidation reaction. During the oxidation of biodiesel, intermediate products and final products are formed so that physical properties also change. Oxidation stability of biodiesel is characterized by test methods by detecting oxidation products or chemical/physical parameters along with accelerated oxidation process. However, there is no method that can cover all stability-related parameters. For example, Rancimat test, detecting the volatile acids produced by decomposition of primary oxidation product, is related with the peroxide value change of biodiesel. Accelerated oxidation method of distillate fuel oil at $95^{\circ} \mathrm{C}$ is related with filterable and adherent insolubles produced during the oxidation. Accelerated oxidation method of distillate fuel oil at $115^{\circ} \mathrm{C}$ is related with carbonic acid produced during oxidation. 


\section{Table 2 Comparison of oxidation stability test methods}

\begin{tabular}{|c|c|c|c|c|c|c|c|c|c|c|}
\hline Method & Standard & Test condition & $\begin{array}{l}\text { Sample } \\
\text { amount }\end{array}$ & $\begin{array}{l}\text { Gas pressure or flow } \\
\text { rate }\end{array}$ & $\begin{array}{l}\text { Temperature } \\
\left({ }^{\circ} \mathrm{C}\right)\end{array}$ & Time & Measured item & $\begin{array}{l}\text { Precision } \\
\text { Repeatability }\end{array}$ & Reproducibility & Ref. \\
\hline Rancimat test & $\begin{array}{l}\text { EN } 14112 \\
\text { ISO } 6886\end{array}$ & Vented glass test tube & $3 \mathrm{~g}$ & Air, $10 \mathrm{~L} / \mathrm{h}$ & 110 & To be measured & $\begin{array}{l}\text { Conductivity change of } \\
\text { vaporized products }\end{array}$ & - & - & [93] \\
\hline $\begin{array}{l}\text { Storage stability at } \\
43^{\circ} \mathrm{C}\end{array}$ & $\begin{array}{l}\text { ASTM D } \\
4625\end{array}$ & $\begin{array}{l}\text { Open borosilicate glass } \\
\text { bottle in dark }\end{array}$ & $50 \mathrm{ml}$ & Air & 43 & $\begin{array}{l}0,4,8,12,18 \\
\text { and } 24 \text { week }\end{array}$ & $\begin{array}{l}\text { Filterable and adherent } \\
\text { insolubles }\end{array}$ & $\begin{array}{l}0.62 \sqrt{\text { the average of two results }} \\
(\mathrm{mg} / 100 \mathrm{ml})\end{array}$ & $\begin{array}{l}2.20 \sqrt{\text { the average of tworesults }} \\
(\mathrm{mg} / 100 \mathrm{ml})\end{array}$ & [94] \\
\hline $\begin{array}{l}\text { Storage stability at } \\
95^{\circ} \mathrm{C}\end{array}$ & $\begin{array}{l}\text { ASTM D } \\
2274\end{array}$ & $\begin{array}{l}\text { Vented borosilicate } \\
\text { glass bottle }\end{array}$ & $350 \mathrm{ml}$ & Oxygen, $3 \mathrm{~L} / \mathrm{h}$ & 95 & $16 \mathrm{~h}$ & $\begin{array}{l}\text { Filterable and adherent } \\
\text { insolubles }\end{array}$ & $\begin{array}{l}0.54 \sqrt[4]{\text { totalinsolubles }} \\
(\mathrm{mg} / 100 \mathrm{ml})\end{array}$ & $\begin{array}{l}1.06 \sqrt[4]{\text { total insolubles }} \\
(\mathrm{mg} / 100 \mathrm{ml})\end{array}$ & [67] \\
\hline $\begin{array}{l}\text { Storage stability at } \\
115^{\circ} \mathrm{C}\end{array}$ & JIS K 2390 & $\begin{array}{l}\text { Vented borosilicate } \\
\text { glass bottle }\end{array}$ & $350 \mathrm{ml}$ & Oxygen, $3 \mathrm{~L} / \mathrm{h}$ & 115 & $16 \mathrm{~h}$ & Acid value & - & - & [71] \\
\hline JFTOT method & $\begin{array}{l}\text { ASTM D } \\
3241\end{array}$ & $\begin{array}{l}\text { 6061-T6 Aluminum } \\
\text { test tube }\end{array}$ & $600 \mathrm{ml}$ & Air & 260 & $2.5 \mathrm{~h}$ & $\begin{array}{l}\text { Deposits formed on heater tube } \\
\text { and plugging rate of filter }\end{array}$ & not possible to specify & & [95] \\
\hline $\begin{array}{l}\text { Induction period } \\
\text { method }\end{array}$ & $\begin{array}{l}\text { ASTM D } \\
525\end{array}$ & Closed pressure vessel & $50 \mathrm{ml}$ & $\begin{array}{l}\text { Oxygen, Initial } \\
\text { pressure at } 690 \text { to } 705 \\
\mathrm{kPa}\end{array}$ & 100 & To be measured & $\begin{array}{l}\text { Induction period for reaching } \\
\text { break point }^{\mathrm{a}}\end{array}$ & Only one case in twenty exceeds $5 \%$ & Only one case in twenty exceeds $10 \%$ & [96] \\
\hline $\begin{array}{l}\text { Rapid small scale } \\
\text { oxidation test }\end{array}$ & $\begin{array}{l}\text { ASTM D } \\
7545\end{array}$ & Closed pressure vessel & $5 \mathrm{ml}$ & $\begin{array}{l}\text { Oxygen, Initial } \\
\text { pressure at } 700 \mathrm{kPa}\end{array}$ & 140 & To be measured & $\begin{array}{l}\text { Induction period for reaching } \\
\text { break point }^{\mathrm{b}}\end{array}$ & Have not been determined & Will be available in or before 2013 & [76] \\
\hline $\begin{array}{l}\text { High temperature } \\
\text { stability }\end{array}$ & $\begin{array}{l}\text { ASTM D } \\
6468\end{array}$ & $\begin{array}{l}\text { Open borosilicate glass } \\
\text { bottle in dark }\end{array}$ & $50 \mathrm{ml}$ & Air & 150 & $\begin{array}{l}1.5 \text { or } 3 \mathrm{~h} \text { (for } \\
\text { fresh sample) }\end{array}$ & Filterable insolubles & $\begin{array}{l}22.42-0.2130 \mathrm{X} \text { for an aging time of } 90 \mathrm{~min} \\
22.55-0.2145 \mathrm{X} \text { for an aging time of } \\
180 \mathrm{~min}\end{array}$ & $\begin{array}{l}44.04-0.4281 \mathrm{X} \text { for an aging time of } 90 \mathrm{~min} \\
34.11-0.3034 \mathrm{X} \text { for an aging time of } 180 \mathrm{~min}\end{array}$ & [97] \\
\hline $\begin{array}{l}\text { Potential residue } \\
\text { method }\end{array}$ & ASTM 873 & Closed pressure vessel & $100 \mathrm{ml}$ & $\begin{array}{l}\text { Oxygen, Initial } \\
\text { pressure at } 690 \text { to } 705 \\
\mathrm{kPa}\end{array}$ & 100 & To be measured & $\begin{array}{l}\text { Sum of potential gums and } \\
\text { precipitate }\end{array}$ & See ref. 98 & See ref. 98 & [98] \\
\hline
\end{tabular}

${ }^{\mathrm{a}}$ : break point - the point in the pressure-time curve that is preceded by a pressure drop of exactly $14 \mathrm{kPa}$ within $15 \mathrm{~min}$ and succeeded by a drop of not less than $14 \mathrm{kPa}$ in $15 \mathrm{~min}$

${ }^{\mathrm{b}}$ : break point — time elapsed between starting the heating procedure of the sample vessel and the break point. 
Most methods use a higher temperature than the real storage temperature in order to accelerate the oxidation reaction and minimized the test time. The choice of temperature is a compromise between test accuracy and test time [99]. A empirical mathematic relationship between test result and temperature has been found for Rancimat test in a temperature range [100]. For other test method, the similar results may also exist. For many reactions, the rate expression can be written as a product of a composition-dependent term and temperature-dependent term named reaction rate. The reaction rate has been found in practically all cases to be well represented by Arrhenius law [101]. It is also possible that some reactions can only take place at higher temperature because of reaction mechanism, and some products can only be detected at specific temperature because of thermal stability of these products and their precursors. More works may need to find the relationship between test result and temperature. It should be noted that if the testing temperature is too high $\left(>100^{\circ} \mathrm{C}\right)$, wrong result may be obtained for some biodiesel sample with special antioxidants due to the evaporation [102]. Beside temperature, air bubbling is used to accelerate the oxidation of Rancimat test, and oxygen aeration as well for storage stability test at $95^{\circ} \mathrm{C}$ or $110^{\circ} \mathrm{C}$.

Due to the differences in accelerating temperature and detecting conditions, largely different results may be given by adopting different test method. It is commonly accepted that biodiesel samples with longer induction period or lower levels of deposits formed in ASTM D2274 test are more stable, but the results of these accelerated tests do not indicate the storage stability in the storage stability test at $43^{\circ} \mathrm{C}[75]$.

In these test methods, Rancimat test (EN 14214 and ISO 6886) and induction period method (ASTM D 525) are predictive methods that can forecast and compare the storage stability of biodiesel in some extent, while other methods have poor predictive abilities and can only distinguish whether the oxidation stability of biodiesel is good or not.

The precision of this method is differing between them. Precision of method includes two items, repeatability and reproducibility. The former one indicates the variation in determination taken by a single operator or instrument under the same condition, while the later means the difference between two independent test results obtained by different operators from different laboratories on the same test material. 


\section{Oxidation stability requirements for various standards}

The first oxidation stability specification requirement included in the biodiesel standard was issued by Czech in 1998 [103], in which, insolubles are required to be lower than $25 \mathrm{~g} / \mathrm{m}^{3}$ determined by ISO 12205. The first oxidation stability specification tested by Rancimat method was issued by Italy in 2001 [104,105], this method was subsequently included in EN biodiesel standard. Until now, Australia, Brazil, China, EU countries, India, New Zealand, The Philippines, Korea and Thailand requiring the oxidation of biodiesel tested by Rancimat should be longer than 6h. Table 3 shows the most important oxidation stability test methods and requirements. There has been a general agreement in the national specifications that a minimum oxidation stability of $6 \mathrm{~h}$ is required using the Rancimat method except for Japan and US. However, under the same storage conditions except for the storage materials, storage time of biodiesel stored in metal tank is greatly shorter than that in plastic tank because of the catalytic effect of metal. Therefore, due to the $80 \%$ occupancy rate of metal tank used for cars in Japan, test method is quite different from the most popular Rancimat method, which is more restricted than $6 \mathrm{~h}$ in Rancimat test. In US, in order to meet the oxidation stability of biodiesel prepared by mostly available feedstocks, requirement is relaxed.

Table 3 Most important oxidation stability test method and requirement

\begin{tabular}{lrrrr}
\hline Biodiesel fuel & $\begin{array}{r}\text { Require } \\
\text { ment }\end{array}$ & Unit & Standard & Test method \\
\hline B100 & $>6$ & $\mathrm{~h}$ & EN 14214 & EN 14112 \\
B100 (heating fuel) & $>4$ & $\mathrm{~h}$ & EN 14213 & EN 14112 \\
B100 & $>3$ & $\mathrm{~h}$ & ASTM D 6751-08 & EN 14112 \\
B6-B20 & $>6$ & $\mathrm{~h}$ & ASTM D 7467-09a & EN 14112 \\
Up to B20 & $>6$ & $\mathrm{~h}$ & EMA Standard & EN 14112 \\
& & & & \\
& $<10$ & $\mathrm{mg} / 100 \mathrm{~mL}$ & EMA Standard & Modified ASTM \\
& & & & D2274 \\
Up to B5 & $<0.12$ & $\mathrm{mgKOH} / \mathrm{g}$ & JIS K 2390 & Modified ASTM \\
& & & & D2274 \\
\hline
\end{tabular}




\section{Future perspective}

Oxidation stability of biodiesel is an important parameter should be monitored for the well operation of engines. A significant amount of efforts and time have been dedicated to the methods being utilized to study oxidation stability of biodiesel. These methods have become the indicators for long-term biodiesel storage. Until now, Rancimat test and accelerated oxidation method of distillate fuel oil at 95 or $115^{\circ} \mathrm{C}$ are the most important methods for oxidation stability testing. These methods are developed to evaluate or predict the storage stability of biodiesel or biodiesel blends under ambient temperature or storage condition. Each of them detects the most important oxidation products or chemical/physical parameters along with accelerated oxidation process. It is not likely that any new method will be able to completely determine and monitor all oxidation-associated parameters by limited procedures.

For the future research on biodiesel stability, two aspects are of significant emphasis, one is the testing method for the determination of biodiesel stability, and the other is to ensure a reasonable limit for oxidation stability specification. For the first one, several proven techniques have been setup for several years, and the modified methods base on these methods are also probable to be included in the new biodiesel specifications in the next few years. For the second one, with the real insight into oxidation characteristics of biodiesel and its aftereffects, reasonable limits for oxidation stability specification accepted by all parts are highly expected.

Beside the proven techniques, other methods such as RSSOT, storage stability at $43^{\circ} \mathrm{C}$, high temperature stability test method and JFTOT method are also potential methods for determination of the oxidation stability of biodiesel.

Unfortunately, there are insufficient standard engine tests to evaluate the impact of fuel stability on fuel system and injector deposits and durability. It is recommended that additional data are need in real equipment both in storage drums and fuel tanks to verify the obtained result.

\section{Executive summary:}

\section{Foundation of oxidation stability test of biodiesel}

Oxidation of biodiesel is an autoxidation process involving the production of hydroperoxide followed by its decomposition and polymerization. 
For hydroperoxide decomposition, oxidation linking of fatty acid chains to form dimer, trimer and oligomer structures with conjugated diene systems is the main route to form high molecular oxidation compounds of esters.

\section{Test methods for stability of biodiesel}

Rancimat test is an automatic method to determine the oxidation stability of biodiesel by monitoring the conductivity change caused by volatile short-chain carboxylic acids from decomposed products of hydroperoxide.

Accelerated oxidation method of distillate fuel oil at 95 or $115^{\circ} \mathrm{C}$ uses oxygen to accelerate the reaction, and the filterable and adherent insolubles or acid value are recorded.

\section{Comparison of some oxidation stability test methods}

The oxidation stability test methods are mainly differing in test temperature, aging time and determining item.

\section{Oxidation stability requirements for various standards}

There has been a general agreement in the national specifications that a minimum oxidation stability of $6 \mathrm{~h}$ is required using the Rancimat method.

\section{Bibliography}

Papers of special note have been highlighted as:

of interest

ם of considerable interest

1. Alan C, Qin Z, Peter W. Ethanol-diesel fuel blends -- a review. Bioresource Technology, 96, 277-285 (2005).

2. Bartholomew. Vegetable oil fuel. Journal of the American Oil Chemists' Society, 58, 286-288 (1981).

3. Pryde EH. Vegetable oil as diesel fuel: overview. Journal of the American Oil Chemists' Society, 60, 1557-1558 (1983).

4. Adams C, Peters JF, Rand MC, Schroer BJ, Ziemke MC. Investigation of soybean oil as a diesel fuel extender: endurance tests. Journal of the American Oil Chemists' Society, 60, 1574-1579 (2001). 
5. Shay EG. Diesel fuel from vegetable oils: status and opportunities. Biomass Bioenergy., 4, 227-242 (1993).

6. Srivastava A, Prassad R. Triglycerides-based diesel fuels. Renewable and sustainable energy Reviews, 4, 14-24 (2000).

7. Katikaneni SPR, Adjaye JD, Idem RO, Bakhshi NB. Performance studies of various cracking catalysts in the conversion of canola oil to fuels and chemicals in a fluidized-bed reactor. Journal of the American Oil Chemists' Society, 75, 381-391 (1998).

8. Lima DG, Soares VCD, Ribeiro EB et al. Diesel-like fuel obtained by pyrolysis of vegetable oils. Journal of Analytical and Applied Pyrolysis, 71(2), $987-996$ (2004).

9. Schwab AW, Bagby MO, Freedman B. Preparation and properties of diesel fuels from vegetable oils. Fuel, 66(10), 1372-1378 (1987).

10. Ziejewski M, K.R KRK, Schwab AW, Pryde EH. Diesel engine evaluation of a nonionic sunflower oil - aqueous ethanol microemulsion. Journal of the American Oil Chemists' Society, (61), 1620-1626 (1984).

11. Mittelbach M, Remschmidt C. Biodiesel-the comprehensive handbook (Boersedruck Ges.m.b.H, Vienna, Graz, Austria, 2004).3-4

- The first comprehensive book on biodiesel

12. Ma F, Clements D, Hanna M. Biodiesel fuel from animal fat. Ancillary studies on transesterification of beef tallow. Industrial \& Engineering Chemistry Research, 37, 3768-3771 (1998).

13. Mittelbach M, Remschmidt C. Biodiesel-the comprehensive handbook (Boersedruck Ges.m.b.H, Graz, Austria, 2004). 148-154

14. Lacoste F, Lagardere L. Quality parameters evolution during biodiesel oxidation using Rancimat test. European Journal of Lipid Science and Technology, 105(3-4), 149-155 (2003).

- Important paper studying the key fuel properties changes during the accelerated oxidation by Rancimat test

15. Leung DYC, Koo BCP, Guo Y. Degradation of biodiesel under different storage conditions. Bioresource Technology, 97(2), 250-256 (2006).

16. Bode HB, Kerkhoff K, Jendrossek D. Bacterial Degradation of Natural and Synthetic Rubber. Biomacromolecules, 2(1), 295-303 (2001). 
17. Baciocchi E, Del Giacco T, Lanzalunga O, Lapi A, Raponi D. The Singlet Oxygen Oxidation of Chlorpromazine and Some Phenothiazine Derivatives. Products and Reaction Mechanisms. The Journal of Organic Chemistry, 72(15), 5912-5915 (2007).

18. Hess PS, O'Hare GA. Oxidation of Linseed Oil. Industrial \& Engineering Chemistry, 42(7), 1424-1431 (1950).

19. Reitsema RH, Cramer FJ. OXIDATION OF PEPPERMINT OIL. Industrial \& Engineering Chemistry, 44(1), 176-180 (1952).

20. Xie G, Barcelona MJ. Sequential Chemical Oxidation and Aerobic Biodegradation of Equivalent Carbon Number-Based Hydrocarbon Fractions in Jet Fuel. Environmental Science \& Technology, 37(20), 4751-4760 (2003).

21. Eser S, Venkataraman R, Altin O. Utility of Temperature-Programmed Oxidation for Characterization of Carbonaceous Deposits from Heated Jet Fuel. Industrial \& Engineering Chemistry Research, 45(26), 8956-8962 (2006).

22. Stadtman ER, Berlett BS. Reactive Oxygen-Mediated Protein Oxidation in Aging and Disease. Chemical Research in Toxicology, 10(5), 485-494 (1997).

23. Bieschke J, Zhang Q, Bosco DA et al. Small Molecule Oxidation Products Trigger Disease-Associated Protein Misfolding. Accounts of Chemical Research, 39(9), 611-619 (2006).

24. Scott G. Antioxidants. Bulletin of the Chemical Society of Japan, 61, 165-170 (1988).

25. Backstrom HLJ. The chain-reaction theory of negative catalysis. Journal of the American Chemical Society, 49(6), 1460-1472 (1927).

26. Saka S. all about biodiesel. Industrial Publishing and Consulting, Inc., Tokyo, Japan, 231 (2004).

a Important comprehensive book covering recent development on biodiesel

27. Chaiyasit W, Elias RJ, McClements DJ, Decker EA. Role of Physical Structures in Bulk Oils on Lipid Oxidation. In: Critical Reviews in Food Science \& Nutrition. (Taylor \& Francis Ltd, 2007) 299-317.

28. Morita M, Tokita M. Hydroxy Radical, Hexanal, and Decadienal Generation by Autocatalysts in Autoxidation of Linoleate Alone and with Eleostearate. Lipids, 43(7), 589-597 (2008).

29. de Guzman R, Tang H, Salley S, Ng K. Synergistic Effects of Antioxidants on the Oxidative Stability of Soybean Oil- and Poultry Fat-Based Biodiesel. Journal of the American Oil Chemists' Society, 86(5), 459-467 (2009). 
30. Selke E, Rohwedder W, Dutton H. Volatile components from triolein heated in air. Journal of the American Oil Chemists' Society, 54(2), 62-67 (1977).

31. Eunok Choe, David B. Min. Mechanisms and Factors for Edible Oil Oxidation. Comprehensive Reviews in Food Science and Food Safety, 5(4), 169-186 (2006).

- Excellent review of the mechanisms of oil and fat oxidation

32. Frankel EN. Lipid Oxidation (The Oily Press, 2005).1-48

- Excellent book of the theory and experiment on oxidation of lipid and its derivatives

33. Zabarnick S, Mick MS. Inhibition of Jet Fuel Oxidation by Addition of Hydroperoxide-Decomposing Species. Industrial \& Engineering Chemistry Research, 38(9), 3557-3563 (1999).

34. Kuprowicz NJ, Zabarnick S, West ZJ, Ervin JS. Use of Measured Species Class Concentrations with Chemical Kinetic Modeling for the Prediction of Autoxidation and Deposition of Jet Fuels. Energy \& Fuels, 21(2), 530-544 (2007).

35. Swern D, Scanlan J, Knight H. Mechanism of the reactions of oxygen with fatty materials. Advances from 1941 through 1946. Journal of the American Oil Chemists' Society, 25(6), 193-200 (1948).

36. Frankel E. Lipid oxidation: Mechanisms, products and biological significance. Journal of the American Oil Chemists' Society, 61(12), 1908-1917 (1984).

37. Batts BD, Fathoni AZ. A literature review on fuel stability studies with particular emphasis on diesel oil. Energy \& Fuels, 5(1), 2-21 (1991).

38. Neff W, Frankel E, Fujimoto K. Autoxidative dimerization of methyl linolenate and its monohydroperoxides, hydroperoxy epidioxides and dihydroperoxides. Journal of the American Oil Chemists' Society, 65(4), 616-623 (1988).

39. Frankel E, Evans C, Cowan J. Thermal dimerization of fatty ester hypdroperoxides. Journal of the American Oil Chemists' Society, 37(9), 418-424 (1960).

40. Miyashita K, Hara N, Fujimoto K, Kaneda T. Dimers formed in oxygenated methyl linoleate hydroperoxides. Lipids, 20(9), 578-587 (1985).

41. Formo MW, Jungermann E, Noris F, Sonntag NOV. Bailey's Industrial Oil And Fat Products, Volume I, (Fourth Edition, Daniel Swern, Editor, John Wiley and Son, 1979). 698-711.

42. Korus R, Mousetis T. Polymerization of safflower and rapeseed oils. Journal of the American Oil Chemists' Society, 61(3), 537-540 (1984). 
43. Lin C-Y, Chiu C-C. Effects of Oxidation during Long-term Storage on the Fuel Properties of Palm Oil-based Biodiesel. Energy \& Fuels, 23(6), 3285 (2009).

44. Bruno TJ, Wolk A, Naydich A. Stabilization of Biodiesel Fuel at Elevated Temperature with Hydrogen Donors: Evaluation with the Advanced Distillation Curve Method. Energy \& Fuels, 23(2), 1015-1023 (2009).

45. Gerhard Knothe. Analysis of oxidized biodiesel by 1 H-NMR and effect of contact area with air. European Journal of Lipid Science and Technology, 108(6), 493-500 (2006).

46. Bondioli P, Gasparoli A, Della Bella $L$ et al. The prediction of biodiesel storage stability. Proposal for a quick test. European Journal of Lipid Science and Technology, 106(12), 822-830 (2004).

47. Bondioli P, Gasparoli A, Della Bella L, Tagliabue S, Guido Toso. Biodiesel stability under commercial storage conditions over one year. European Journal of Lipid Science and Technology, 105(12), 735-741 (2003).

48. deMan J, Tie F, deMan L. Formation of short chain volatile organic acids in the automated AOM method. Journal of the American Oil Chemists' Society, 64(7), 993-996 (1987).

49. McCormick RL, Ratcliff M, Moens L, Lawrence R. Several factors affecting the stability of biodiesel in standard accelerated tests. Fuel Processing Technology, 88(7), 651-657 (2007).

50. EN 14214. Automotive fuels - Fatty acid methyl esters (FAME) for diesel engines -Requirements and test methods. (2003).

51. ASTM D 6571-08. Standard specification for biodiesel fuel blend stock (B100) for middle distillate fuels. ASTM International, (2008).

52. Hadorn H, Zurcher K. Zur Bestimmung der Oxydations-stabilitat von Olen und Fetten. Dtsch Lebensm Rundsch, 70, 57-65 (1974).

53. ISO 6886. Animal and vegetable fats and oils -- Determination of oxidative stability (accelerated oxidation test). (2006).

54. ISO 6886. Animal and vegetable fats and oils -- Determination of oxidative stability (accelerated oxidation test). (1996).

55. ASTM D 7467-08. Specification for Diesel Fuel Oil, Biodiesel Blend (B6 to 20). (2008).

56. ASTM D 396-08b. Specification for Fuel Oils, adds biodiesel blend specifications up to $5 \%$ by volume (B5). (2008). 
57. GB/T 20828-2007. Biodiesel blend stock (BD100) for diesel engine fuels. Standardization Administration of the People's Republic of China, (2007).

58. Report of the BIOSTAB project results, Stability of Biodiesel, Used as a Fuel for Diesel Engines and Heating Systems. (Published by BLT Wieselburg, Austria, 2003)

ane most important work for the implementation of Rancimat method as one of standard methods for oxidation stability test of biodiesel

59. Westbrook SR. An Evaluation and Comparison of Test Methods to Measure the Oxidation Stability of Neat Biodiesel (Southwest Research Institute San Antonio, Texas 2005)

60. EN 15751. Automotive fuels - Fatty acid methyl esters (FAME) fuel and blends with diesel fuel - Determination of oxidation stability by accelerated oxidation method; German version (2008).

61. ISO 12205. Petroleum products - Determination of the oxidation stability of distillate fuels. (1995).

62. DIN EN 590. Automotive fuels -Diesel -Requirements and test methods. (2006).

63. ASTM D 7467-09a. Standard Specification for Diesel Fuel Oil, Biodiesel Blend (B6 to B20). (2009).

64. ASTM D 6571-07b. Standard specification for biodiesel fuel blend stock (B100) for middle distillate fuels. ASTM International, (2007).

65. ASTM D 6571-09. Standard specification for biodiesel fuel blend stock (B100) for middle distillate fuels. ASTM International, (2009).

66. Tang H, Abunasser N, Wang A et al. Quality survey of biodiesel blends sold at retail stations. Fuel, 87(13-14), 2951-2955 (2008).

67. ASTM D 2274. Standard test method for oxidation stability of distillate fuel oil (accelerated method). ASTM International, (2003).

68. ASTM D 6571-03. Standard specification for biodiesel fuel blend stock (B100) for middle distillate fuels. ASTM International, (2003).

69. Engine Manufactures Association of American, Test Specifications for Biodiesel Fuel. (Chicago, Illinois, 2006)

70. ASTM D7462-08 Standard Test Method for Oxidation Stability of Biodiesel (B100) and Blends of Biodiesel with Middle Distillate Petroleum Fuel (Accelerated Method). (2008). 
71. JIS K 2390: 2008. Automotive fuels -- Fatty acid methyl ester (FAME) as blend stock. Japanese Industrial Standards Committee, (2008).

72. Report of Advanced Industrial Science and Technology (AIST) and New Energy and Industrial Technology Development Organization (NEDO), Applicability of 100\% biodiesel fuel for common-rail fuel injection system. May, 2007.

73. Sarin A, Arora R, Singh NP, Sharma M, Malhotra RK. Influence of metal contaminants on oxidation stability of Jatropha biodiesel. Energy, 34(9), 1271-1275 (2009)

74. ASTM D 4625. Standard Test Method for Distillate Fuel Storage Stability at $43^{\circ} \mathrm{C}$ $\left(110^{\circ}\right.$ F). ASTM International, (2004).

75. McCormick RL, Westbrook SR. Empirical study of the stability of biodiesel and biodiesel blends, Milestone Report. (National Renewable Energy Laboratory, 2007)

76. ASTM D 7545-09. Standard test method for oxidation stability of middle distillate fuels-rapid small scale oxidation test (RSSOT). ASTM International, (2009).

77. Polavka J, Paligová J, Cvengroš J, Simon P. Oxidation stability of methyl esters studied by differential thermal analysis and rancimat. Journal of the American Oil Chemists' Society, 82(7), 519-524 (2005).

78. Dantas M, Almeida A, Conceição M et al. Characterization and kinetic compensation effect of corn biodiesel. Journal of Thermal Analysis and Calorimetry, 87(3), 847-851 (2007).

79. Conceição MM, Candeia RA, Silva FC et al. Thermoanalytical characterization of castor oil biodiesel. Renewable and Sustainable Energy Reviews, 11(5), 964-975 (2007).

80. Santos N, Tavares M, Rosenhaim $\mathbf{R}$ et al. Thermogravimetric and calorimetric evaluation of babassu biodiesel obtained by the methanol route. Journal of Thermal Analysis and Calorimetry, 87(3), 649-652 (2007).

81. Du Plessis L, De Villiers J, Van Der Walt W. Stability studies on methyl and ethyl fatty acid esters of sunflower seed oil. Journal of the American Oil Chemists' Society, 62(4), 748-752 (1985).

n The first work studied the oxidation stability of fatty acids esters used as automobile fuel

82. Du Plessis LM. Plant oils as diesel fuel extenders: Stability tests and specifications on different grades of sunflower seed and soybean oils. CHEMSA, 8(11), 150-154 (1982).

83. Bondioli P, Gasparoli A, Lanzani A et al. Storage stability of biodiesel. Journal of the American Oil Chemists' Society, 72(6), 699-702 (1995). 
84. Mittelbach M, Gangl S. Long storage stability of biodiesel made from rapeseed and used frying oil. Journal of the American Oil Chemists' Society, 78(6), 573-577 (2001).

85. Paolo Bondioli, Ada Gasparoli, Laura Della Bella, Silvia Tagliabue, Guido Toso. Biodiesel stability under commercial storage conditions over one year. European Journal of Lipid Science and Technology, 105(12), 735-741 (2003).

86. Paligova J, Jorikova L, Cvengros J. Study of FAME Stability. Energy \& Fuels, 22(3), 1991-1996 (2008).

87. Martín-Polvillo M, Márquez-Ruiz G, Dobarganes M. Oxidative stability of sunflower oils differing in unsaturation degree during long-term storage at room temperature. Journal of the American Oil Chemists' Society, 81(6), $577-583$ (2004).

88. Bouaid A, Martinez M, Aracil J. Long storage stability of biodiesel from vegetable and used frying oils. Fuel, 86(16), 2596-2602 (2007).

89. Das LM, Bora DK, Pradhan S, Naik MK, Naik SN. Long-term storage stability of biodiesel produced from Karanja oil. Fuel, In Press, Corrected Proof).

90. Knothe G. Some aspects of biodiesel oxidative stability. Fuel Processing Technology, 88(7), 669-677 (2007).

91. Paolo Bondioli, Ada Gasparoli, Della Bella L, Silvia Tagliabue. Evaluation of biodiesel storage stability using reference methods. European Journal of Lipid Science and Technology, 104(12), 777-784 (2002).

92. Dunn R. Effect of oxidation under accelerated conditions on fuel properties of methyl soyate (biodiesel). Journal of the American Oil Chemists' Society, 79(9), 915-920 (2002).

93. EN 14112. Fat and oil derivatives. Fatty acid methyl esters (FAME). Determination of oxidation stability (accelerated oxidation test). Beuth Verlag GmbH, (2003).

94. D $4625-92$. Standard Test Method for Distillate Fuel Storage Stability at $43^{\circ} \mathrm{C}\left(110^{\circ} \mathrm{F}\right)$. ASTM International, (1998).

95. D 3241 - 02a. Standard Test Method for Thermal Oxidation Stability of Aviation Turbine Fuels (JFTOT Procedure). ASTM International, (2002).

96. ASTM D 525-01. Standard Test Method for Oxidation Stability of Gasoline (Induction Period Method). ASTM International, (2001).

97. ASTM D 6468. Standard test method for high temperature stability of distillate fuels. ASTM International, (1999). 
98. ASTM D 873 - 99a. Standard Test Method for Oxidation Stability of Aviation Fuels (Potential Residue Method). ASTM International, (1999).

99. Berthiaume D, Tremblay A. NRCan project \# CO414 CETC-327 report, Study of the Rancimat Test Method in Measuring the Oxidation Stability of Biodiesel Ester and Blends. (OLEOTEK Inc., 2006)

100. Xin J, Imahara H, Saka S. Kinetics on the oxidation of biodiesel stabilized with antioxidant. Fuel, 88(2), 282-286 (2009).

101. Levenspiel O. Chemical Reaction Engineering (John Wiley and Sons, Inc., new York, 2002).27-29

102. Mittelbach M, Schober S. The influence of antioxidants on the oxidation stability of biodiesel. Journal of the American Oil Chemists' Society, 80(8), 817-823 (2003).

103. CSN 65 6509. Motorova paliva-Palivo pro vznetove motory s obsahem methylesteru repkoveho oleje do $5 \%$ - technicke pozadavky a metody zkouseni. CSNI, Czech, (1998).

104. UNI 10946. Automotive fuels-fatty acid methyl esters (FAME) for diesel engines Requirements and test methods. UNI, Italy, (2001).

105. UNI 10947. Heating oils- fatty acid methyl esters (FAME) for diesel engines Requirements and test methods. (2001).

201. Draft standard for fuel parameters (biodiesel) http://www.environment.gov.au/atmosphere/fuelquality/publications/draft-standard.htm l. (2003)

202. Furui K. World Trends of Biodiesel Standards. (Beijing, China, 2008) http://www.jari.or.jp/ja/kankohbutsu/hokoku/rt_ja/rt2009_ja.html (access on July 8, 2009)

203. Determination of Biodiesel Oxidation and Thermal Stability. http://www.biodiesel.org/resources/reportsdatabase/reports/gen/19970212_gen-230.pdf (access on July 8, 2009) 


\section{Definitions of keywords}

Biodiesel: mono alkyl esters derived from vegetable oils and animal fats through transesterification reaction

Oxidation stability: resistance to change its fuel properties because of oxidation reaction

Thermal stability: resistance to the relatively high temperature stress for short period of time

Storage stability: resistance to the deteriorating effect in storage over extended period of time

Specification: an explicit set of requirements to be satisfied

Standard: an established norm or requirement for technical criteria or engineering, methods, processes and practices

Accelerated oxidation: uses elevated temperature and/or oxygen/air aeration to quicken the oxidation reaction

Autoxidation: occurs in presence of oxygen and forms hydroperoxides through free radical chain reaction

Rancimat test: a method to determine the oxidation stability of oils/fat and its derivatives 